\title{
Natural History and Ecology of the Yellow-bellied Day Gecko (Cnemaspis flaviventralis) in Maharashtra, India
}

\author{
Amit Sayyed \\ Wildlife Protection and Research Society, India (amitsayyedsatara@gmail.com)
}

Photographs by the author.

$\mathrm{T}$ he genus Cnemaspis Strauch 1887 is one of the speciose genera in the family Gekkonidae with nearly 140 currently recognized species (Uetz et al. 2018) that are distributed in southern and southeastern Asia and tropical Africa. However, recent molecular phylogenetic analyses (Gamble et al. 2012; Pyron et al. 2013; Zheng and Wiens 2016; Cyriac et al. 2018; Sayyed et al. 2018) determined that the genus Cnemaspis is not monophyletic.

Geckos in this genus are characterized by slender, clawed, and rarely dilated digits, with the two distal phalanges compressed and forming an angle with the basal portion of the digits, the lower surfaces of which bear rows of plates; bodies more or less depressed with granular or tubercular dorsal scales; tails more or less cylindrical; pupils round; eyelids distinct; males with or without preanal or femoral pores; well-developed hypo-ischia, post-anal bones and sacs, and a reduced hyoid apparatus with only one pair of basibranchials; presence of three or four sternal ribs; interclavicles well developed and cruciform (in the Oriental species) or much reduced and with only very small transverse arms (in the African spe- cies); adhesive toe pads absent (in the Oriental species) or present (in the African species); leaf toes and paraphalanges absent (Smith 1935; Gamble et al. 2012; Sayyed et al. 2018). Recent discoveries of several new species of this genus from India have elevated the number of species in that nation to 35, with eight of them present in the northern Western Ghats of Maharashtra.

Based on four males and four females, Sayyed et al. (2016) described Cnemaspis flaviventralis (Fig. 1) from the Amboli $\left(15.9600^{\circ} \mathrm{N} .73 .9990^{\circ} \mathrm{E}\right.$; elev. $735 \mathrm{~m}$ asl), Sindhudurg District, Maharashtra, India. To date, this species has been known only from the original description and the type locality, although the range has been estimated to be $177 \mathrm{~km}^{2}$. Herein I describe breeding behavior, incubation period, clutch sizes, and communal nesting in $C$. flaviventralis.

I observed Cnemaspis flaviventralis at the type locality from 2015 to 2018. Amboli lies in the hill ranges of the northern Western Ghats of Maharashtra, India. The climate is moist-tropical, with about $3,589 \mathrm{~mm}$ of precipitation annually, most falling in July (averaging 1,557 mm compared
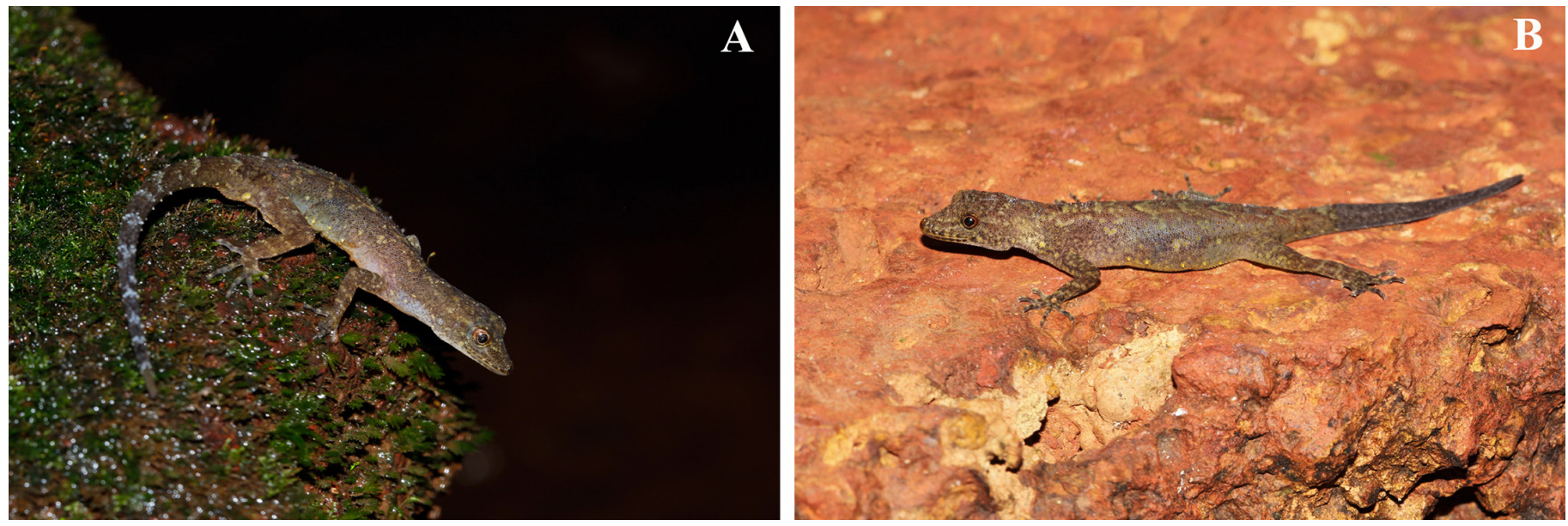

Fig. 1. Yellow-bellied Day Geckos (Cnemaspis flaviventralis): (A) non-breeding adult male; (B) adult female. 
with the driest month of January with $0 \mathrm{~mm}$ of rain; http:// climate-data.org). Temperatures range from 22 to $27^{\circ} \mathrm{C}$, with an average of $23.9^{\circ} \mathrm{C}$.

Cnemaspis flaviventralis is semi-arboreal on trees and rocks, where they use crevices, loose bark, tree holes, and even gaps between branches as refugia. These geckos occasionally venture onto the ground for feeding and can be found in leaflitter at such times.

I observed geckos throughout the year but found the most eggs during July to December and considerably fewer during January to June, which is suggestive of year-round breeding but with the greatest recruitment occurring during the rainy season. Dominant males compete with other adult and sometimes subadult males to establish and protect a territory, in which the dominant male lives with several females during the breeding session. Competitive encounters begin with males flicking their tails and by raising their bodies on extended limbs. If such a display is insufficient, fights escalate to aggressive biting, which can result in dropped tails, tearing of skin, and sometimes a loss of toes.

During the breeding season, the colors of both adult males and females become brighter (Fig. 2A). Adult females, which are larger than adult males, appear to choose the largest, most brightly colored males, which are approached while tailflicking until the male initiates copulation. Successful copulation lasts about 30 seconds. Females lay eggs within 15 to 25 days after copulation and tend to congregate during this period near communal nesting sites under rocks, in tree holes, and even in crevices of human-made structures, where females deposit two white oval eggs. I found four communal nests: (1) 38 eggs in a human-made structure (Fig. 2B), (2) 22 eggs in a rock crevice in dense forest, (3) nine eggs in a tree hole, and (4) 16 eggs between two rocks. Nests contained between five and 38 eggs, with more during the rainy season and fewer during the dry months. Most nesting sites are high above the ground and out of direct sunlight. Incubation varied from 45 to 90 days, with the duration apparently dependent on temperature.
Females left the nest sites after ovideposition and I observed no indications of parental care. Hatchlings can be abundant in the vicinity of communal nests until they disperse (Fig. 3A).

Both genetic and environmental sex determination are known in geckos (e.g., Viets et al. 1994). When we incubated eggs of several other species of Cnemaspis, we maintained temperatures of $26-32{ }^{\circ} \mathrm{C}$ and found that incubation temperatures of $30-32{ }^{\circ} \mathrm{C}$ resulted in males and temperatures below $30{ }^{\circ} \mathrm{C}$ resulted in females. Average temperature at the type locality of $C$. flaviventralis was $23.9^{\circ} \mathrm{C}$, suggesting that studies are necessary to confirm the method of sex determination in this species.

Cnemaspis flaviventralis feeds on grasshoppers, flies, beetles, butterflies, small cockroaches (Fig. 3B), mosquitoes, ants, and termites. Adults opportunistically take caterpillars and spiders, and I observed one adult feeding on a Maharashtra Bush Frog (Raorchestes bombayensis) froglet during the rainy season.

Amphibian and reptilian species observed in the vicinity of the type locality included Khaire's Black Shieldtail (Melanophidium khairei), another shieldtail (Uropeltis sp.), Kolhapur Day Gecko (Cnemaspis kolhapurensis), Amboli Day Gecko (Cnemaspis amboliensis), Malabar Flying Frog (Rhacophorus malabaricus), Amboli Leaping Frog (Indirana chiravasi), and Amboli Toad (Xanthophryne tigerina). In addition, during the rainy season, I encountered the Common Krait (Bungarus caeruleus), Malabar Pitviper (Trimeresurus malabaricus), Travancore Wolfsnake (Lycodon travancoricus), Green Keelback (Macropisthodon plumbicolor), Bombay Leaftoed Gecko (Hemidactylus prashadi), another house gecko (Hemidactylus sp,), Deccan Banded Gecko (Geckoella albofasciatus), Maharashtra Bush Frog (Raorchestes bombayensis), and Amboli Bush Frog (Pseudophilautus amboli) in close proximity to the communal nests.

Major threats to the species include habitat loss, development for tourism, and habitat disturbance by enthusiastic visitors and photographers. Populations of Cnemaspis flaviventralis appear to be highly localized and the entire known range
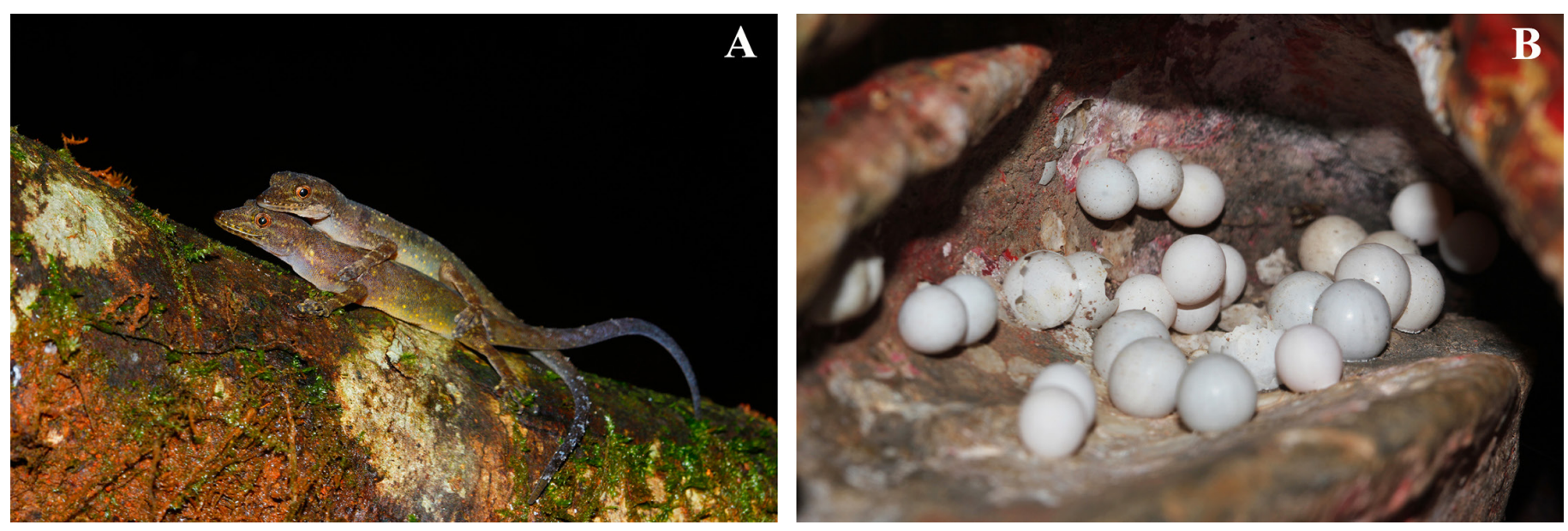

Fig. 2. Yellow-bellied Day Geckos (Cnemaspis flaviventralis): (A) male and female in copula; (B) communal nesting in a human-made structure. 

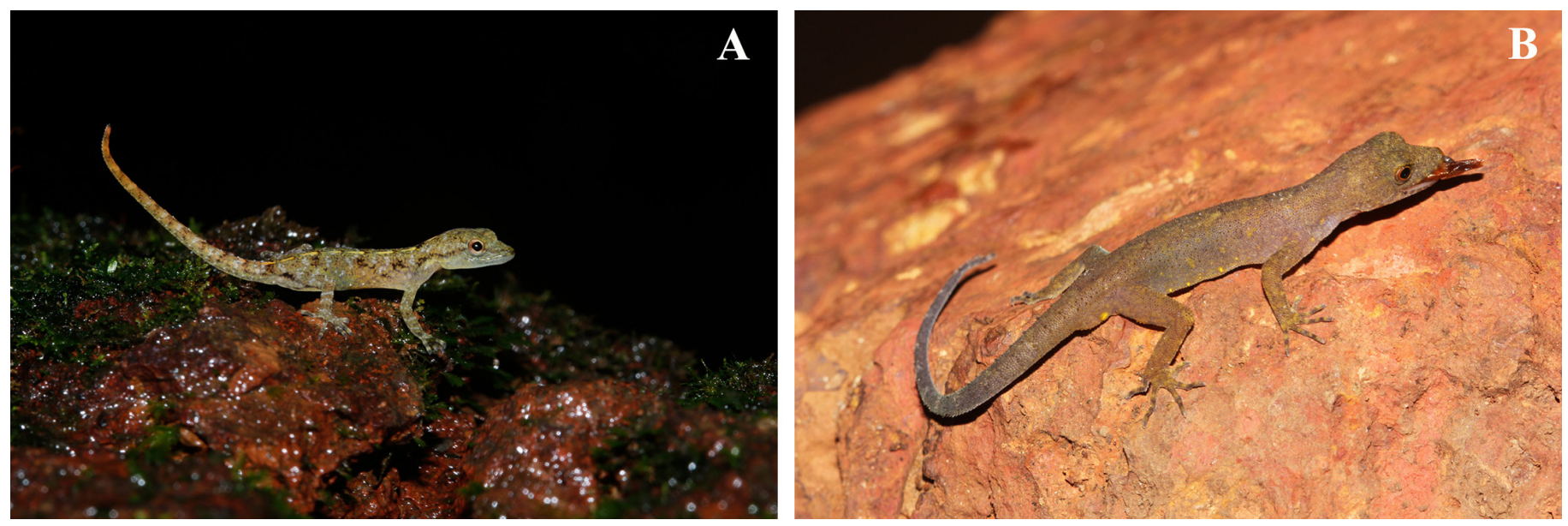

Fig. 3. Yellow-bellied Day Geckos (Cnemaspis flaviventralis): (A) Juvenile in nature; (B) adult male feeding on an insect.

of the species is small and does not include any protected areas. Although the species has not been assessed for the IUCN Red List, based on listed criteria (IUCN 2012), it should warrant a listing of endangered. Several other endemic species of flora and fauna, some critically endangered, occur at Amboli; consequently the protection of habitat is an urgent priority.

\section{Acknowledgements}

I thank Abhijit Nale, Rohit Katke, Rahul Thombre, Mangesh Karve, Devendra Bhosle, Aman Adsul, Nikhil Mutha, Kiran Ahire, Vikas Jagtap, Mudassar Narwade, Ashitosh Suryawanshi, and Hrishikesh Awale, members of Wildlife Protection and Research Society, for their help in the field.

\section{Literature Cited}

Cyriac, V.P., A. Johny, P.K. Umesh, and J.P. Muhamed. 2018. Description of two new species of Cnemaspis Strauch, 1887 (Squamata: Gekkonidae) from the
Western Ghats of Kerala, India. Zootaxa 4459: 85-100.

Gamble, T., E. Greenbaum, T.R. Jackman, A.P. Russell, and A.M. Bauer. 2012. Repeated origin and loss of adhesive toepads in geckos. PLoS ONE 7: e39429.

IUCN (International Union for the Conservation of Nature). 2012. IUCN Red List Categories and Criteria. Version 3.1. 2nd ed. IUCN, Gland, Switzerland and Cambridge, UK.

Pyron, R.A., F.T. Burbrink, and J.J. Wiens. 2013. A phylogeny and revised classification of Squamata, including 4161 species of lizards and snakes. BMC Evolutionary Biology 13: 1-53.

Sayyed, A., R.A. Pyron, and N. Dahanukar. 2016. Cnemaspis flaviventralis, a new species of gecko (Squamata: Gekkonidae) from the Western Ghats of Maharashtra, India. Journal of Threatened Taxa 8: 9619-9629.

Smith, M.A. 1935. The Fauna of British India, Including Ceylon and Burma. Reptilia and Amphibia. Vol. II.-Sauria. Taylor and Francis Ltd., London, UK.

Uetz, P., P. Freed, and J. Hošek (eds.). 2018. The Reptile Database (http://www. reptile-database.org).

Viets, B.E., M.A. Ewert, L.G. Talent, and C.E. Nelson. 1994. Sex-determining mechanisms in squamate reptiles. Journal of Experimental Zoology 270: 45-56.

Zheng, Y. and J.J. Wiens, 2016. Combining phylogenomic and supermatrix approaches, and a time-calibrated phylogeny for squamate reptiles (lizards and snakes) based on 52 genes and 4162 species. Molecular Phylogenetics and Eevolution 94: 537-547. 